\title{
IN THE FOOTSTEPS OF ALONSO RAMÍREZ
}

\author{
Two Decades in Pursuit of the Most Elusive American Pirate
}

The first reprint of the Infortunios de Alonso Ramirez (Misfortunes of Alonso Ramirez) was published in Madrid in 1902 in volume 20 of the "Collection of Rare and Curious Books That Deal with America." It was directly transcribed from the only surviving copy known to date of the original edition printed in México City in 1690 that was then in the possession of Manuel Pérez de Guzmán y Boza, the first Marquis of Jerez de los Caballeros. ${ }^{2}$ At the time, Guzmán y Boza’s collection of Spanish manuscripts and rare books was second only in importance to that of the National Library in Madrid, and the marquis was negotiating the sale of all its titles to Archer M. Huntington, who would use the more than ten thousand works to establish the library of the Hispanic Society of America in New York City in 1904. That is how, two centuries after its publication in México, this brief pamphlet, scarcely forty pages in length, made its return trip across the Atlantic. Lost among so many crates, the only surviving copy of the Infortunios must have seemed a lackluster piece of an invaluable treasure. At first glance, it was an object of little value, a small pamphlet typical of the countless popularly priced publications that during the seventeenth century came to flood the burgeoning public sphere in cities from Antwerp to Manila with news, oddities, and all sorts of accounts, among which the most popular were, invariably, the stories of travels and discoveries. Moreover, it was printed on low-quality paper with irregular type, showing signs of having been prepared rather hastily. For Huntington and his agents, this brief book could not have compared in value with

1. Carlos de Sigüenza y Góngora, Infortunios de Alonso Ramírez, Colección de libros raros y curiosos que tratan de América 20 (Madrid: Imprenta de la viuda de G. Pedraza, 1902).

2. The work was listed as part of the collection in the catalog published in 1898. See Catálogo de la biblioteca del Excmo. Sr. D. Manuel Pérez de Guzmán y Boza, marqués de Jerez de los Caballeros: Primera parte (Seville, 1898), 127. 
the vellum-bound incunabula they had been acquiring during the previous two decades in a systematic search for Spanish patrimony all over Europe. Hence it is not surprising that the work that was already priced in Madrid as rare and curious was disregarded in New York City, where it remained filed away in the library's collection for almost a century until Estelle Irizarry found it, dusted it off, and had the good sense of publishing it in facsimile as part of her interesting study and special tercentennial edition. ${ }^{3}$

All the while, the Madrid edition of 1902 gave birth to an entire school dedicated to the study of the little book that some have identified as the founding text in the tradition of the Latin American novel. It was consecrated as such by Antonio Castro Leal, who placed the Infortunios at the head of his monumental survey in two volumes, La novela del México colonial (The novel of colonial México), preceded by a prologue that stated in its first sentence: "This narration can well be considered a novel." ${ }^{4}$ To date, there have been at least twentyfive Spanish-language editions of the Infortunios published as interest in the work spread from Spain to México, Argentina to Puerto Rico, Venezuela to the United States, and now, most recently, to Cuba. The book is without a doubt the most widely read work of Carlos de Sigüenza y Góngora, who as a writer, mathematician, astronomer, geographer, antiquarian, and philosopher was arguably the most distinguished intellectual of the Novo Hispanic baroque, even if the literary genius of the time was his close friend Juana Inés de la Cruz. ${ }^{5}$ For this reason, it is obligatory reading in Spanish American colonial literature courses in universities throughout the world. Yet for all the broad distribution of the work in Spanish, until very recently, there have been few deep and critical studies on the Infortunios, while documented research, in terms of both the production of the work as well as the people and events mentioned in it, continues to be scarce.

The main obstacle to the study of the text is that even for native Spanish speakers and literary scholars, the work has a fair amount of unintelligible passages. This is partly due to the conditions that resulted in the production of the book as well as to the way the first Madrid edition was subsequently treated in its many reprints during the course of the twentieth century. Most reprints have unknowingly reproduced a series of errors in the 1902 edition. That edition, in turn, was carrying many typographical errors as well as omissions and misplaced references from the original book. Add to this the long technical passages in the work

3. Carlos de Sigüenza y Góngora, Infortunios de Alonso Ramírez, ed. Estelle Irizarry (Río Piedras: Editorial Cultural, 1990).

4. Carlos de Sigüenza y Góngora, "Infortunios de Alonso Ramírez," in La novela del México colonial, ed. Antonio Castro Leal, vol. 1 (México, D.F.: Aguilar, 1964), 51. For a discussion of the scholarship concerning the work, see the introduction to one of the most recent editions published in Spain, prepared by José Manuel Camacho Delgado. José Manuel Camacho Delgado, introduction to Infortunios de Alonso Ramírez seguido de Alboroto y motín de los indios de México, by Carlos de Sigüenza y Góngora (Seville: Ediciones Espuela de Plata, 2008), 9-54. 5. I use the term Novo Hispanic in the same sense as the Spanish novohispano to denote all that pertains to the former Viceroyalty of New Spain and its society. 
dealing with matters of hydrography and navigation that systematically have been neglected when not altogether overlooked, almost without exception, by editors and critics on both sides of the Atlantic. Still, there is no greater complication in this brief work than the uneasy coupling, seldom in tandem, of two formidable personalities who during the summer of 1690 entered into a dangerous and daring game of vested and cunning interests that they maintain to this day. Consider first that the original text was hastily put together in little less than two months during the early summer of 1690 by Carlos de Sigüenza y Góngora, a writer who held it to be a matter of family honor to practice the art of the most ultrabaroque Spanish gongorino-style prose, often flirting with incoherence, as the reader will soon discover. Then imagine what a challenge it was for Sigüenza to attempt to make sense of the story brought to him by Alonso Ramírez, a man of dubious provenance who had a way with words and, arguably, quite a colorful and captivating personality. At the time, Ramírez was skillfully managing his interest to profit from the uncommon exploit of having been the first Spaniard since Juan Sebastián Elcano to have traveled around the world while at the same time trying not to raise any suspicion concerning his exploits during the time he was allegedly being held captive by English pirates in the South Seas. It is obvious, moreover, that Sigüenza used this plot to promote his own personal, class-based interests and that he seems to have been guilty of concealment. In other words, this narrative, laden with the weight of editorial errors and language that drifts between technicality and artifice, is anchored to the very uncertain bottom of a highly unstable and surreptitious tale. As Sigüenza set out to chart that submerged landscape, throwing and pulling up the sound repeatedly, he managed only to turn the waters increasingly murky. In its infinitely complex, delicate, and unstable form, this work will continue to seduce the reader, openly or through deceit, defying all attempts to be fully reduced by reason.

The critical study of the Infortunios has been limited until now to the domain of Spanish and Mexican letters. In that realm, it has been handled almost exclusively by literary scholars who, for the most part and until very recently, seemed to be solely concerned with assigning the work to a particular genre within the tradition and debating whether it is a true account. ${ }^{6}$ Those who have considered it a true

6. Julie Greer Johnson argues for the classification of the work under the Spanish picaresque tradition. See Julie Greer Johnson, "Picaresque Elements in Carlos Sigüenza y Góngora's Los Infortunios de Alonso Ramirez," Hispania 64.1 (1981): 60-67. For the case in favor of the historical veracity of the work, see J. S. Cummins, "Infortunios de Alonso Ramirez: 'A Just History of Fact'?" Bulletin of Hispanic Studies 61.3 (1984): 295-303. Álvaro Félix Bolaños criticizes this debate by stating that "it limits the Infortunios within two models of Renaissance discursive narrative." See Álvaro Félix Bolaños, "Sobre las 'relaciones' e identidades en crisis: El 'otro' lado del ex-cautivo Alonso Ramírez," Revista de crítica literaria latinoamericana 21.42 (1995): 133. Further still, in his Historia de la novela hispanoamericana, Fernando Alegría mentions the Infortunios as a work that borrows certain characteristics from the novel while warning of critics who "ill-at-ease with the lack of novels in the colonial period . . . have taken great care to invent a 'novelesque tradition' by giving credit for artistic creation to historical and 
account have ventured into the discussion of authorship to begin exploring the complex interaction between a heavy-handed writer and the transient spokesman who is the protagonist of the story. ${ }^{7}$ Beyond that, this fascinating tale of a young boy from San Juan, Puerto Rico, who set out to sea in search of fortune and ended up circumnavigating the globe, halfway through his travels suffering a terrible ordeal at the hands of English pirates, remained inaccessible until very recently to a broader Spanish-speaking readership and to everyone unable to access the text in its original language. The first English translation of the Misfortunes, published in México in 1962 , was plagued with errors to such a degree as to be completely useless. ${ }^{8}$ Since 2011, the translation by Fabio López Lázaro has been available to English-language readers. Unfortunately, this version adds much language that is not contained in the original text. It is also full of inaccuracies and errors. ${ }^{9}$

Now for the first time there is a bilingual edition that corrects the mistakes in all previous Spanish reprints of the original 1690 edition while being the most authoritative and definitive English translation, going far beyond all previous scholarship in documenting Ramírez's journey and a story that makes an art form out of subterfuge. Having the two versions side by side will also help students in survey courses of Latin American colonial literature as well as Spanish-language readers and scholars in general get greater access to a text that has baffled even the experts due to its ultrabaroque language, technical passages pertaining to nautical knowledge, and the purposeful, deceitful intentions of Ramírez as well as Sigüenza. This Rutgers edition of the Infortunios/Misfortunes is based on my critical edition of the Infortunios published jointly in Madrid by the Spanish High Council for Scientific Research (CSIC) and Ediciones Polifemo in 2011. Then as now, the work aims to explore in depth the blind spots in a century of study in Spanish philology by placing the Infortunios/Misfortunes against the backdrop of historical sources and paying close attention to all matters of hydrography and navigation, ideology and representation.

The work at hand aspires to be the authoritative edition of Sigüenza's most famous work, finally placing the precious pamphlet within reach of a global readership of students, scholars, and the curious at heart. Beyond López Lázaro’s claim that the book describes the "true adventures of a Spanish American with

didactical works." See Fernando Alegría, Historia de la novela hispanoamericana (México City: Ediciones de Andrea, 1974), 11.

7. One of the latest and most significant works in this respect is Estelle Irizarry's study. It is centered on a computer analysis comparing the Infortunios with other accounts by Siguienza trying to quantify the number of words and expressions that can be attributed to him or to Ramírez. See Estelle Irizarry, "Análisis por computadora: datos significativos," in Irizarry, ed., Infortunios de Alonso Ramírez (Río Piedras: Editorial Cultural, 1990), 51-65.

8. Carlos de Sigüenza y Góngora, The Misadventures of Alonso Ramírez, trans. Edwin H. Pleasants (México: Imprenta Mexicana, 1962). Starting with the very same title of the work, Pleasants's is nothing short of a complete mistranslation of the Infortunios.

9. Fabio López Lázaro, The Misfortunes of Alonso Ramirez: The True Adventures of a Spanish American with 17th-Century Pirates (Austin: University of Texas Press, 2011). 
seventeenth-century pirates," this first bilingual edition uncovers the treasure trove of competing stories gifted to us by a Spanish American pirate who was, as I first proved in my 2009 Cuban edition of Sigüenza's historical works, the first American to circumnavigate the globe whom we know by name. ${ }^{10}$ Finally, English speakers will be able to follow closely Ramírez's exploits from San Juan to Acapulco, Manila, Jakarta, and Chennai, from Australia to Madagascar, rounding off the Cape of Good Hope to head back across the Atlantic Ocean into the Caribbean Sea, bearing witness to the trials of Ramírez as his ship runs aground on the coast of Yucatán and culminating in the castaway's unlikely audience with Gaspar de la Cerda Silva Sandoval y Mendoza, Count of Galve and viceroy of New Spain. It is our hope that the reader will find in this edition the tools to continue to decipher a fascinating and inexhaustible text that promises to reveal some of the most delicate and unsuspected operations in the early fashioning, evolution, and forging of American subjectivity. Indeed, this work grants us exclusive access to the thinking process of the modern colonial subject and the world view of what in Spanish were known as gente de mar, or "people of the sea," sailors and expatriates whose lives and legacies have been continuously undervalued in the history of nations.

With this in mind, most documentation and explanations have been consigned to the notes in the Spanish transcription and correction of the 1690 edition as well as its English translation. This gives all readers multiple paths for immediate access to the work while also pointing students, scholars, and the curious at large in the direction of further possible research and inquiry. The critical essay is designed to serve as a pilot book of sorts, guiding the reader past the whirlpool that until now has claimed most inquiry on the work and out into the uncharted waters where the story of Alonso Ramírez's alleged misfortunes is still a journey into the pleasures of the most destabilizing approach to sanctioned forms of power and knowledge in the modern world. Indeed, my aim is to guide the reader's careful approach to the Infortunios/Misfortunes as a work of ideological piracy.

The present edition is the result of two decades of archival research in Spain and México, of a sailing voyage through the Virgin Islands, and of three expeditions to the most remote and inaccessible parts of the Costa Maya in Quintana Roo, México, formerly known as the Bacalar coast in the Yucatán Peninsula. I had conducted a previous and very preliminary investigation on the work at the Archive of the Indies (AGI) in Seville in 1999. The result of those findings appeared in my first book. ${ }^{11}$ But it was not until the summer of 2003 that I was able to begin a systematic search to establish, once and for all, the historical basis of the story and the possible existence of its protagonist. Keep in mind that, as stated in

10. See José F. Buscaglia-Salgado, introduction to Historias del Seno Mexicano, by Carlos de Sigüenza y Góngora, ed. José F. Buscaglia-Salgado and Reynier Pérez Hernández (Havana: Casa de las Américas, 2009), 17.

11. See José F. Buscaglia-Salgado, Undoing Empire, Race and Nation in the Mulatto Caribbean (Minneapolis: University of Minnesota Press, 2003), 128-72. 
one of the latest editions of the Infortunios, published in Spain in 2008, it was still possible until very recently for scholars to say that "although many of the facts that turn up in the Infortunios are apparently true and real, the truth is that they remain uncorroborated. So, for example, it has been impossible to certify to this day the existence of the castaway Alonso Ramírez and, as a consequence, all the adventures he lived through lack the most basic support in truth." 12 A year later, after a decade of tracking the footsteps of my distant and elusive countryman, I was able to declare in my introduction to Historias del Seno Mexicano, published in Havana, that among other significant evidence, in the summer of 2004 I had found not just the site of Alonso Ramírez's shipwreck on the coast of Bacalar in Yucatán but also, three years later in 2007, his marriage certificate to Francisca Javiera in México City in 1682 (see figures 11 and 6, respectively). Finally, after a century of scholarly speculation, I was able to settle the question of Alonso Ramírez's existence using direct and irrefutable proof. The path I followed to this major set of discoveries has yielded the wealth of information and new knowledge that we now present to our readers.

My first major attempt to tackle the question of Alonso Ramírez's existence yielded modest results and a growing realization that the book and the person on whose life it was supposedly based were not going to reveal their secrets in a forthcoming way. The research conducted in Seville during a handful of days in the summer of 2003 allowed me to confirm the existence of a good number of secondary characters in the text. I was also able to make some conjectures concerning the still unresolved issue of Ramírez's paternal ancestry. Yet I was not able to find any mention of Alonso Ramírez or, at least, of the Alonso Ramírez I was searching for. I was convinced that Sigüenza would not have dared to challenge the Inquisition by putting forth as veridic a fictional account dealing with a plebeian character whose misadventures touched on the lives of a plethora of royal and ecclesiastical officials, many of whom he knew personally and on some of whom he was dependent for his livelihood and very subsistence. Hence I began to consider the possibility that the name Alonso Ramírez might have been a pseudonym. In that way, I figured that the real story could have been told and denied all at once, releasing from any obligation all those who could have had any sort of contact with the alleged castaway. Moreover, as his aggressive commandeering of the story might suggest, I figured that this could have been a way for Sigüenza to cut off the oral testimonial from ever being able to push or lay any claim against the written narrative. But if that were the case, how would I ever find the person behind the character?

This question forced me to alter the course of the research. Being a sailor, like Ramírez, I took to the sea. Following the very detailed description in the book, I spent that winter constructing a map of the route taken by Ramírez when allegedly navigating without charts or a readable pilot book through the Caribbean

12. Camacho Delgado, introduction, 32-33. This is my translation. 
Sea. In the spring of 2004, I sailed through the Narrows in the Virgin Islands, the very same area where, as described in chapter V, Ramírez found himself "surrounded by islets between two big islands." There I confirmed that the island of Puerto Rico is within sight of any vessel heading westward from that point. I was always suspicious that there was no mention of Ramírez's native Puerto Rico in what is otherwise such a precise description of the route that one could sail by it (see map 7). It became immediately clear to me that contrary to what is alleged in the book, Ramírez's aim was not to return to Spanish territory-at least not immediately or in a direct fashion. But where was he going when he was run aground by a tempest? The answer to that question began to take shape as I set out to examine the prevailing winds and currents in the area as well as the circumstances and reference points cited in the book in relation with that terrible accident.

Based on that information, I was able to draw a map of the eastern coast of Yucatán, pinpointing with remarkable exactitude the place where his ship would have run aground after crossing the Chinchorro Reef on a south-by-southwest course. I narrowed down the area of the shipwreck to a five-kilometer stretch of shoreline along the coast of Bacalar. In the summer of 2004, I traveled to the fishing village of Xcalak, the last Mexican settlement on the southeastern coast of Yucatán. I spent three days surveying the entire shoreline by traveling along the lonely dirt road that traverses what has remained a major area of contraband and piracy since Ramírez's time to the present. There I immediately confirmed the great accuracy of the geographic descriptions given in the book. By the second day, I had found three major landmarks mentioned by Ramírez and was able to prove, without any doubt, that I had identified the precise location of the shipwreck site, lying, as is indicated with remarkable accuracy in chapter VI, almost equidistant, by a length of about four Spanish land leagues, between two bodies of water known today as the Huache and Bermejo Rivers (see figures 15 and 16).

I could hardly believe that I was standing on the precise spot where the shipwreck had taken place 315 years before. Looking at the horizon from the broken and very sharp, rocky outcrop of Herradura Point, I imagined the horror experienced the night of the shipwreck as if I had been there, and I was moved by the thought of what it would have been like to be stuck in a place so remote, desolate, and without shelter. By that point, I no longer had any doubt whatsoever that we were dealing with a story that Sigüenza received from somebody else, whether or not the name of that person was Alonso Ramírez. That stretch of coast remained officially uncharted and unexplored until the end of the eighteenth century, when territorial disputes between Spain and England forced both kingdoms to take a closer look at the area that would initially become known as British Yucatán. At the time, these Mayan lands were frequented by pirates based in the area known today as Stann Creek and the Wallace or Belize River. This vast frontier zone was purposefully off-limits to Spanish subjects as part of a 
long-standing strategic plan to protect the Gulf of Campeche by denying English pirates shelter and access to resources, especially roads to penetrate beyond the coast. The Mayans were the only ones who knew the area well, especially the precise location of all fresh-water springs in that vast mangrove forest that is otherwise utterly inhospitable to humans. Indeed, the first detailed Spanish maps of the Bacalar coast, like those of the province of Yucatán circa 1734, lack any definition in the outline of the territory lying between Ascensión Bay and Boca de Cangrejos (near present-day Xcalak), the stretch of coast that the castaways traveled through. ${ }^{13}$ Therefore, it would have been impossible for Sigüenza, who until then had never ventured far from México City, to give an accurate topographic description of such remote and officially unknown places.

In my excitement at the find, I jumped into the water off the very point where, according to the book, the ship had run aground. Over the next two hours, I proceeded to systematically dive in search of any signs of the vessel, looking around the entire tip of the point and thirty meters out to sea primarily for cannons and ordinance on an ocean floor covered completely by rocks and coral. The force of the waves breaking against the sharp rock and the very real solitude of the land and sea all around me made me abandon the search at dusk without finding any single piece of evidence.

With a renewed sense of optimism at having precise topographic confirmation of the veracity of the story, I continued looking for Ramírez all over México. I traveled the old royal roads that go from Veracruz, via Perote, to Puebla de los Ángeles and México City. I followed his wanderings through the sierras all the way to the old city of Antequera, today Oaxaca de Juárez, and in Yucatán, I walked the same Mayan road, or sacbe, he followed from Tihosuco to Valladolid and spent time looking for traces of him in the massive Franciscan monastery of Izamal, where he allegedly spent Holy Week of 1689 (see figures 25 to 26). In the National Archives in México City (AGN), I found records of a significant number of military officers named Alonso Ramírez. None of them, however, could have been the subject in question. Then when everything seemed to be heading down a dead end, I found some fascinating and very valuable information dealing with the scandalous Inquisitorial trial of the woman who allegedly was Ramírez's mother-in-law. This would prove to be key in composing a truer picture of young Alonso's character and intentions.

The following summer, I returned to Seville. I was determined to find the report that should have been sent to Madrid explaining the circumstances surrounding the capture by English pirates of the royal frigate that, according to the text, was under the command of Alonso Ramírez. Midday on the fourth day of the five-day research stint, I located an extensive dossier of documents giving a full account of several acts of piracy perpetrated near Manila and on the island of Mindanao. As I read hurriedly through the hundreds of pages, trying to decide

13. See AGI, MP-México, 119. 
which documents to photocopy before returning home the next day, I almost stopped breathing when I encountered a paragraph with a description of the capture of the royal frigate Our Lady of Aránzazu that was practically identical to the corresponding passage in the Infortunios. As the reader will soon discover, that find yielded many more questions than answers. We now have a precise list for the crew of the frigate, yet the name Alonso Ramírez is not there. The master of Our Lady of Aránzazu was called Felipe Ferrer.

In the summer of 2006, I returned once more to Seville, hoping to find the load manifest and passenger lists of the Santa Rosa galleon aboard which Ramírez supposedly sailed from Acapulco to Manila. I was also aiming to locate the itemized notation of the payment allegedly received by Ramírez by order of the viceroy of New Spain as compensation for the mistreatment he claimed to have suffered at the hands of his English captors. Both searches were unsuccessful. Yet I uncovered sufficient documentation on Captain Felipe Ferrer as to conclude that he was a different person from, and much older than, Alonso Ramírez. As I did three years prior when facing a similar impasse in the archival research, I decided to go back to the text and to the coast of Bacalar for answers.

This time I prepared for the expedition by mapping the entire path taken along the coast during the fifty-two days that Ramírez and his men were marooned. The book gives a detailed day-by-day account. After carefully adding up all the distance traveled, I was able to estimate that they were rescued in the vicinity of Piedra Point some sixty-three nautical miles north of the shipwreck site (see figure 17). With that information and knowing that their Mayan rescuers guided them to drink fresh water in a nearby building that the text describes in detail, I went looking for the ruins of the structure. The satellite images of that stretch of coast commonly available at the time were of very low resolution. Yet through some circuitous online research, I was able to locate a sports fishing center in a remote point on Pájaros Island, south of Ascensión Bay, where three of my students and I were to be graciously welcomed in March of 2007 and given all the assistance needed to move through the mangrove channels and lagoons by canoe just like Ramírez had done three centuries before. Thanks to the generosity of our hosts, we managed to access and document what today is known as the Tupac ruins and to discover, deep inside the forest and thanks to the clues in the text, the very watering hole where Ramírez and his men quenched their seven-week thirst (see figures 18 to 20). Once again, just as in Herradura Point three years before, I felt that the distance between Alonso and myself had been reduced almost to the point of disappearance. Yet the closer I got, the more he still managed to skillfully elude me.

I wasted no time in going straight back to the National Archives in México City. I needed to find the only document that could settle the issue of our real character's name once and for all. If indeed he married the niece of the dean of the Metropolitan Cathedral in México City, there should have been documentation 
attesting to the fact. I had searched for it before following the timeline in the book and assuming that if he left Acapulco for Manila in 1682, then he must have been married in 1680 or 1681 . No records had turned up then. This time I decided to do a line-by-line search of the books containing all the marriages of Spaniards and Spanish Creoles in the cathedral of México City starting in January 1679. As it turned out, the document did exist, but the original at the AGN had been lost. I was able, however, to find the reference and with it a copy in the Historical Archive of the Archbishopric of México City (AHAM). Finally, I had him before me. As stated in the text, Alonso Ramírez was married to Francisca Javiera, the niece of Juan de Poblete (see figure 6). The question of his true name, if not that of his multiple possible identities, had been settled once and for all and so had the issue of his social provenance, as he was officially considered a Spaniard and not a caste. Yet, as with the list of the crew of Our Lady of Aránzazu, there are significant discrepancies between the account and the documents. The ceremony took place on November 8, 1682. Thus Ramírez could not have been aboard the Santa Rosa, as the text reports, since on the day of the wedding, the galleon was in the harbor of San Jacinto in the Philippines and, unable to make the crossing that year, would return to Manila on December 13. As I explain in detail in the essay, further research would show that the book is doubly mistaken on these points. The only galleon that year was the San Antonio de Padua. It left Acapulco on Friday, March 27, seven months prior to Ramírez's marriage in México City.

Given all this information and adding to it the data obtained on site pertaining to distances, topography, climate, prevailing winds, and currents, I now had sufficient material to construct the first accurate timeline of the life and travels of the very real person known as Alonso Ramírez. That timeline became the backbone to the carefully documented Madrid edition that is the foundation of this first bilingual version of the Infortunios/Misfortunes.

Still, when Kimberly Guinta offered me the opportunity to publish the bilingual edition with Rutgers University Press, I knew that I had one more major task to fulfill in my search for Alonso Ramírez. I had to go back to the shipwreck site at Herradura Point. For years I had been hesitant to do this out of fear that calling attention to whatever remains could be found would very possibly lead to looting by the locals. I also feared for my safety and that of those around me, as this stretch of coast is still a dangerous frontier zone. Luckily, Dante García Sedano, a former student of mine who is now an archaeologist and a cave-diving master, had just established a company for underwater archaeology research and was able to organize a four-day expedition to Punta Herradura right around the time when the final book manuscript was due. The findings are momentous: nails, fasteners, and European pottery of the exact period; a very long piece of the ship's hull; and a small cannon. Even though during the entire expedition we faced fifteen- to twenty-knot winds, two-meter-high waves, and a very strong northerly current that did not allow us to dive on the very point, I am confident that we have 
discovered and documented part of the remains of the ship lying close to shore on the north side of Herradura Point.

Finally, I had in my hands part of what Alonso Ramírez claimed as his property, and I felt that I was embracing him across time and space, at once welcoming him from his long voyage around the globe and promising him at long last due recognition for such a great feat. I now place before you, dear reader, the abundant loot contained in what is not simply a pirate's story but, more important, a truly piratical narrative in the most extensive measure of possibility. My hope is that, finally, a wide global readership will be able to enjoy, reflect upon, and study the first narrative based on the life of a true and real subject from the Caribbean Islands whom we now know to be the first American to have traveled around the world.

José F. Buscaglia-Salgado y Ramírez Herradura Point, Quintana Roo, México

Thursday, February 22, 2018 
